DOI: https://doi.org/10.15688/jvolsu4.2021.2.4

UDC 94(3+430)“1275”

Submitted: 27.02 .2020

LBC 63.3(0)4

Accepted: 14.05 .2020

\title{
TWO “IDENTICAL" FREIBURG CHARTERS OF 1275. SHORT DRAFT
}

\author{
Pavel A. Blokhin \\ Astrakhan State University, Astrakhan, Russian Federation
}

\begin{abstract}
Introduction. In 1275, two drafts of town law of Freiburg im Breisgau were created. This article presents an analysis of one of these texts, namely the short draft. Methods and materials. The main research method is comparative historical analysis. The contents of two charters are compared, namely the 1218 Rodel draft and the short draft of 1275 . Analysis. There are 6 thematic clusters uniting the laws by branches of law: 1) privileges of citizens and rights of the Town Lord; 2) criminal procedure law; 3) civil law; 4) town administration; 5) trade law; 6) various laws. The first part of the laws from the short draft is a translation of the Rodelian laws, the second one represents reformulated Rodelian norms, while the last one contains new laws in the legislation of Freiburg. Results. Though the document did not become an official town charter, it manifested the changes in the town law of the $13^{\text {th }}$ century, compared to the previous 1218 Town Charter. In addition, the laws in the draft reflected the political struggle for power between the Town Lord of Freiburg, the City Council of 24 and the town community. The Town Lord regained his previously lost rights, in particular the legislative initiative. However, at the same time, the short draft significantly limited Lord's arbitrariness towards the property of citizens as well as Freiburg citizens themselves. According to the short draft, the City Council of 24 strengthened and expanded its power in the town, becoming a full-fledged legislative and executive body of the town administration. The town community, on the other hand, was losing its privileges and rights, for example, it lost the opportunity to elect some of the civil servants and members of the Council of 24 .
\end{abstract}

Key words: Freiburg im Breisgau, medieval town law, short draft of 1275, Rodel, town community.

Citation. Blokhin P.A. Two "Identical" Freiburg Charters of 1275. Short Draft. Vestnik Volgogradskogo gosudarstvennogo universiteta. Seriya 4. Istoriya. Regionovedenie. Mezhdunarodnye otnosheniya [Science Journal of Volgograd State University. History. Area Studies. International Relations], 2021, vol. 26, no. 2, pp. 56-67. (in Russian). DOI: https://doi.org/10.15688/jvolsu4.2021.2.4

УДК 94(3+430)“1275”

Дата поступления статьи: 27.02.2020

ББК 63.3(0)4

Дата принятия статьи: 14.05 .2020

\section{ДВЕ «ОДИНАКОВЫЕ» ФРАЙБУРГСКИЕ ХАРТИИ 1275 Г.: КРАТКИЙ ПРОЕКТ}

\section{Павел Александрович Блохин}

Астраханский государственный университет, г. Астрахань, Российская Федерация 
вое право; 6) разные законы. Результаты. Документ, несмотря на то что он не стал официальной хартией, зафиксировал изменения, произошедшие в городском законодательстве в XIII в. по сравнению с предыдущей фрайбургской городской хартией 1218 года. Кроме того, в законах проекта отразились стороны политической борьбы, происходившей между сеньором Фрайбурга, городским Советом 24-х и общиной города.

Ключевые слова: Фрайбург в Брайсгау, средневековое городское право, краткий проект 1275 г., Родель, городская коммуна.

Цитирование. Блохин П. А. Две «одинаковые» фрайбургские хартии 1275 г.: краткий проект // Вестник Волгоградского государственного университета. Серия 4, История. Регионоведение. Международные отношения. -2021. - Т. 26, № 2. - C. 56-67. - DOI: https://doi.org/10.15688/jvolsu4.2021.2.4

Введение. Во второй половине XIII начале XIV в. коллекция фрайбургских юридических документов пополнилась новыми текстами. Это два проекта городских хартий 1275 г. (краткий проект [5, Bd. II, S. 656-671] и пространный проект [10, S. 74-87]), официальная фрайбургская хартия 1293 г. [10, S. 123139], соглашение графа Конрада с горожанами 1316 г. [10, S. 208-210].

В 1275 г. были созданы два проекта городских хартий, которые не получили официальный статус, то есть не были приняты и не имели хождения в городе. Оба документа так и остались проектами, поскольку в это время основные стороны, заинтересованные в появлении новой хартии - горожане и городской сеньор - не смогли договориться о наиболее важных для них нормах [5, Bd. I, S. 219-293].

Работа с немецкоязычными проектами предполагает объемный анализ. Настоящая статья - это вторая часть большого трехчастного исследования. Первая часть была опубликована в виде моей статьи «Две “одинаковые” фрайбургские хартии 1275 г.: cui bono?» в сборнике «Средние века» [1]. В этой работе анализируется проблема возможного авторства проектов, дается общая характеристика текстов 1275 г. в сравнении с предыдущими сборниками законов Фрайбурга (начиная с 1275 г.), делается попытка определить причины, по которым проекты так и не стали официальными городскими хартиями и т. п. Оба проекта создавались в условиях борьбы трех политических сил: городского сеньора, старшего и младшего Советов 24-х - органов городского управления. Интересы двух из них - сеньора и старшего Совета - совпадали, и в случае, если проекты были бы приняты, властные полномочия могли быть распределены между ними. Однако и сеньору, и старшему Совету противостоял младший Совет 24-х - контролирую- щий орган власти во Фрайбурге, возникший в 1248 г., которому было невыгодно появление новых сборников законов в том варианте, как они были представлены в проектах 1275 года. Создание немецкоязычных проектов городских законов, а также то, что они не стали официальными фрайбургскими хартиями, является продолжением затяжного политического конфликта между городом и сеньором, с одной стороны, и между различными социально-политическими группировками в городе - с другой. В 1275 г. в политической жизни города сложилась патовая ситуация, требовавшая дальнейшего политико-правового разрешения.

В третьей части исследования будет сделана попытка рассмотрения пространного проекта в сравнении с текстом краткого проекта, характеристика и анализ которого представлены в настоящей статье.

Методы и материалы. Несмотря на то что оба проекта не стали официальными сборниками фрайбургских законов, содержание этих документов представляет интерес, поскольку, с одной стороны, показывает эволюцию правовой системы в средневековом Фрайбурге, а с другой - отражает изменения, произошедшие в социально-экономической и политической жизни города между 1218 г. (временем принятия предыдущей фрайбургской хартии) и 1275 г., зафиксированные в законах. В связи с этим в данной статье основным методом исследования будет выступать сравнительно-исторический анализ. Основное сравнение содержательной части краткого проекта будет проведено с так называемым Штадтроделем (или просто - Роделем) - предыдущей фрайбургской хартией.

В 1218 г. городу была представлена хартия, получившая официальный статус - Родель. Г. Шрайбер в 1828 г. издал полный вариант документа, снабдив латинский текст 
немецким переводом. Он же разбил сплошной текст на 80 параграфов + Пролог [10, S. $3-$ 25 ; 3 , c. $15-16$; 4, с. 15-45].

Исследования Роделя сводились в основном к установлению даты создания текста и определению подлинности документа. Шрайбер на первых порах полагал, что документ написан в 1120 г., поскольку в тексте имеется указание, что Бертольд герцог фон Церинген основал город в 1120 году. Ритшель посчитал, что Родель был написан в период между 1272 и 1275 гг., во время, когда обострилась борьба за наследство двух братьев - графов фон Фрайбургов [8, S. 29]. Исследователь полемизирует в данном случае с Г. Фламмом, который настаивал на том, что текст был создан в 1218 г., в момент смены династий [8, S. 25-29]. Палеографические исследования Рерига [9] и Лаузена [7], сравнивавших стиль письма Роделя и иных фрайбургских источников XIII в., отнесли время создания текста к периоду между 1217 и 1247 годами. Точку в споре поставил Ганемайер [6], проведя тщательное палеографическое исследование и доказав, что дата создания источника - 1218 год.

Родель написан на латыни, включает в свой состав Пролог и 80 параграфов. Документ имеет ряд новых законов по сравнению с юридическими текстами XII - начала XIII века. Примечательно, что все новые нормы отражают интересы горожан, то есть они были написаны либо в интересах и для блага городской общины, либо ограничивали права сеньора.

Краткий проект 1275 г. был опубликован в 1995 г. [5, Bd. II, S. 656-671]. Источник практически «выпал» из исследовательского пространства фрайбургской историографии. Характеристику проекту дала М. Блаттманн, однако таковая была, по словам историка, «технической», то есть содержательная сторона документа, его влияние на политико-правовую систему города во второй половине XIII в. историком практически не учитывались [5, Bd. I, S. 285].

Краткий проект написан на Mittelhochdeutsch, имеет 81 параграф, Пролог и Эпилог. Законы по сравнению с ранними фрайбургскими хартиями упорядочены и приведены в определенную систему: нормы объединены в отраслевые блоки. На документе, в силу того что текст проекта не стал официальной хартией, нет и никогда не было печатей сеньора города и самого города, не стоят подписи под текстом. Краткий проект написан от имени сеньора города - графа Эгона (Эгино) II фон Фрайбурга (1271-1316).

Анализ. Из краткого проекта «исчезли» три нормы, присутствующие в Роделе: § 70 закон о запрете строительства дома на средства иногороднего, $\S 80$ - установление о лишении сеньора города законодательной инициативы и $§ 75$ - норма о расследовании уголовного преступления - ранения.

$\S 80$ вместе с $\S 4$ (закон о наследовании Фрайбурга старшим сыном сеньора) Роделя стали самыми важными в политике ограничения городом сеньориальной власти. Фактически § 4 запрещал свободное распоряжение Фрайбургом сеньору. Город отныне становился для новой сеньориальной семьи собственностью, которой последние не могли распоряжаться в полной мере. Любая форма отчуждения Фрайбурга, за исключением наследования старшим сыном, была для сеньоров недоступна. Это была важная победа горожан, обезопасивших себя от возможных неприятностей, связанных с феодальными усобицами и борьбой феодальных групп за Фрайбург. Краткий проект (§ 1) повторяет роделевский закон, прибавляя, что если сыновей у сеньора нет, то наследовать власть над городом должна старшая дочь.

$\S 80$ также состоит из двух законов. В первой и третьей частях параграфа (§ 80 ч. 1 и $\S 80$ ч. 3) устанавливалась ответственность сеньора перед законом: нарушение сеньором городских норм означало, что он «игнорирует право города». В подобном случае сеньориальное правонарушение не отменяло закон как прецедент, но, наоборот, установление городских властей «сколько раз [сеньор такое решение] нарушит, столько раз [оно будет заново] приниматься». Вторая часть параграфа (§ 80 ч. 2) отнимает законодательную инициативу у господина города. Указано, что всякое новое постановление городских властей должно быть утверждено в обязательном порядке: «...решение, [что] будет сделано, также [господину] надлежит принять». По сути, сеньоры лишились законодательной власти в городе. Они могли отныне только 
регистрировать закон, принятый городскими властями. В случае же, если сеньор и намеревался издать норму, которая могла быть неугодна фрайбургскому муниципальному управлению, такой закон отклонялся. Права сеньоров в городе были ограничены. Краткий проект не имеет подобного закона в своем составе. Граф Эгон II решил взять своеобразный реванш за вынужденное умаление власти, случившееся в начале правления его деда графа Эгона I (1218-1237).

Пролог краткого проекта 1275 г. заметно отличается от Пролога Роделя. В последнем использовалась формула, появившаяся еще во Фрайбургской учредительной привилегии 1120 г. [2, с. 71-85; 5, Bd. II, S. 531-533]: каждый новый законодатель указывал, что он предоставляет хартию городу, который он же основал в 1120 г., а законы в этой хартии базируются на так называемом кельнском праве. Пролог же краткого проекта ссылается на предыдущую хартию, написанную от имени герцога Бертольда V Церингена (сеньора Фрайбурга в 1186-1218 гг.), основанную на кельнском праве и подтвержденную императором и его прямыми вассалами. В качестве причины создания нового правового документа указывалось физическое обветшание старой хартии.

В Роделе нет Эпилога. В кратком же проекте он содержит клятву графа Эгона II, что он будет соблюдать положения новой хартии, указания, что документ запечатан графской печатью (хотя, как было сказано выше, проект не имел печатей).

Таким образом, граф Эгон II доказывал свою легитимность как законодателя, а ссылка на раннюю хартию придавала новому документу дополнительную значимость и указывала преемстсвенность власти для графского рода от предыдущих сеньоров Фрайбурга - герцогов Церингенов.

Остальные нормы, по примеру создателей краткого проекта, будут разбиты на блоки. Их 6, выделенных по отраслям права: 1) привилегии горожан и права сеньора $\S \S 1-8$, 24-29, 51; 2) уголовно-процессуальное право $\S \S 9-19,23,30-33,35-37,50,59,61-64$; 3) гражданское право $\S \S 20-22,34,38-49,52$; 4) муниципальное управление $\S 55-58,65$; 5) торговое право $\S \S 71-81$; 6) разные законы $\S \S 60,66-70$.
Первый блок - привилегии горожан и права сеньора. 5 параграфов краткого проекта содержат прямой перевод 6 параграфов Роделя: $\S 4$ (=§ 5 Роделя) - закон о защите прибывающих во Фрайбург; $§ 5$ (=§ 7 Роделя) - право свободно и безопасно навсегда покинуть город для фрайбуржца; § 24 (=§ 51 Роделя) - разрешение лично зависимому поселиться во Фрайбурге и право господина возвратить такого зависимого; $§ 25$ (=§ 52 Роделя) - право «года и дня» для новопоселенца; § 51 (=§§ 64-65 Роделя) - наказание за преступление против фрайбуржца, совершенное во время военного похода, и наказание за отказ от участия в военном походе, объявленном сеньором.

9 параграфов отличаются от имеющихся в Роделе (о законе 1-го параграфа см. выше). § 2 (изм. § 2 Роделя) содержит нормы о размере участка для постройки дома для фрайбуржца и о сумме чинша сеньору за такой участок. В Роделе установлен срок уплаты чинша - день св. Мартина (11 ноября), а его сумма устанавливалась в 12 денариев. В кратком проекте чинш определялся в один шиллинг пфеннигами (einin Schilling pfenninge). Составители проекта просто заменили латинский денарий на немецкоязычный шиллинг пфеннигами, а сумма выплаты не изменилась. И это при том, что в том же самом проекте, но в других законах, используются латинские номиналы - денарий и обол (§ 75) [5, Bd. II, S. 668-669]. Изменилось время внесения шиллинга в казну. Теперь горожанин был обязан платить в период от дня св. Мартина до Рождества. По всей видимости, не все горожане успевали вовремя заплатить либо некоторые из них не платили положенный чинш, мотивируя свой отказ сжатыми сроками выплаты и, соответственно, нехваткой времени, и законодатель увеличил время чиншевого сбора почти на полтора месяца - с 11 ноября по 25 декабря.

$\S 3$ (изм. § 63 Роделя) дополняет закон о военной службе горожан в пользу сеньора. Как и в Роделе, в кратком проекте было указано, что горожане выступают в составе армии сеньора на время «одного дня пути» (от Фрайбурга). Как дополнение выступает положение о защите жизни и имущества горожанина, вероятно, во время несения им военной службы. 


\section{ВЛАСТЬ И ОБЩЕСТВО}

$\S 6$ (изм. § 8 Роделя) - закон о выборе городского священника. В Роделе устанавливалось, что городская община выбирает для себя священника. Однако, как указывает краткий проект, сеньор города, по всей видимости, посчитал такую привилегию излишней и присвоил право выбора себе. Скорее всего, графу нужна была дополнительная поддержка в городе, поэтому он предпочел в качестве священника иметь верного себе человека. Все же в том же законе указывается, что пономари (министранты - sigristen) должны быть выбраны горожанами.

$\S 7$ (изм. § 10 Роделя) по новому определял выборы шультгейса (schultheizen) - верховного городского судьи по гражданским и уголовным делам. В Роделе такой выбор принадлежит горожанам. В кратком проекте Сеньор города утверждает шультгейса «от 24-х»городского Совета. В данном случае не вполне ясно, был ли новый шультгейс избран советниками либо же он избирался из состава самого Совета. Как бы то ни было, данная норма укрепляла позиции городского Совета и ущемляла права городской общины.

Фрайбургский Совет 24-х - орган муниципального управления, возникает еще в 1120 г. как коллегия присяжных, занимающаяся вопросами функционирования рынка. В 1120 г. число присяжных еще не определено [5, Bd. II, S. 531-532]. В дальнейшем коллегия присяжных получает дополнительные властные прерогативы, постепенно превращаясь в полноценный городской Совет, состоящий из 24-х членов.

$\S 8$ продолжает изменения в законе о выборах городских служащих (§ 10 Роделя). Кроме шультгейса горожане, по закону Роделя, избирали стражников (lictores) и пастухов (pastores). В новом законе горожане выбирали надзирателя (stokwertir) и пастуха (herter). Сложность идентификации латинского lictor позволяет предположить идентичность должностей стражника и надзирателя, хотя такое предположение лишено документального подтверждения. Однако в новом законе существует разночтение. В Роделе должностных лиц избирали ежегодно, в кратком проекте - «когда угодно». Это обеспечивало частую сменяемость неугодных для горожан должностных лиц.
$\S 26$ (изм. § 61 Роделя) указывает, что после смерти фрайбуржца, бывшего при жизни зависимым и признававшего свою зависимость, наследство покойного не доставалось бывшему господину. В старом законе говорилось, что вдова зависимого бывшему господину ее покойного мужа «ничего не дает». Таким образом, из закона Роделя исключались ситуации, когда жена умирала раньше мужа и после смерти мужчины оставались другие наследники, например дети. Краткий проект исправил этот случай.

$\S 27$ (изм. § 23 Роделя) меняет основное условие включения жителя Фрайбурга в состав городской общины. Родель определял таким условием владение недвижимостью в городе стоимостью в 1 марку. Краткий проект смягчал такоеусловие: полноправным горожанином мог стать любой, кто владел $1 / 8$ частью дома, который стоит 2 марки. Особо указывалось, что такой дом не должен быть ветхим. Новый закон увеличивал число полноправных горожан членов городской общины.

$\S 29$ (изм. § 36 Роделя) конкретизирует норму о запрете людям сеньора города становиться горожанами. В Роделе такими людьми названы hominum uel ministerialium domini - «люди или министериалы господина». Краткий проект указывает, что это «собственные люди господина» (herrin eigin lût... Вариант перевода - «родня господина»), «люди его фогта»- верховного судьи сеньориальной администрации (siner vogt lutt) и «служилые люди» (dienest mañe). Таким образом, в круг лиц, которым был запрещен допуск в городскую общину, были добавлены служащие при господском фогте. Все они, как указано в обоих документах, могли стать свидетелями против горожан, что делало судопроизводство предвзятым. Отсюда - жесткий запрет группе лиц становиться горожанами Фрайбурга, за исключением случая, когда сеньор не освобождал бы их от своих обязанностей.

Наконец, один параграф является новым для фрайбургского законодательства. § 28 развивает закон об условии включения в состав городской общины (см. выше, § 27). Новая норма постановляет, что дети покойного горожанина, владевшего 1/8 частью дома, становились полноценными горожанами «как много бы их ни было» (swie vil der ist). Одна- 
ко если такой наследник потеряет право владения отцовским наследством, то он лишается возможности стать полноценным членом городской общины. Вернуть право наследования надлежало в течении года.

Законы 1-го блока имеют два основных вектора: во-первых, прослеживаются тенденции к усилению сеньориальной власти и расширению полномочий Совета. Во-вторых, обнаруживается направленность к дополнительному привлечению новопоселенцев в город. Законы, облегчающие положение зависимых горожан, упрощающие получение допуска в городскую общину, должны были привлечь в город новых жителей.

Второй блок - уголовно-прочессуальное право. 11 параграфов являются прямым переводом норм Роделя: § 13 (=§ 46 Роделя) разграничивал полномочия судебной власти сеньора и шультгейса: во власти господина города были дела против согорожан о вырывании волос, побоях, проникновении с преступными намерениями в дом, пленении и соучастии в пленении. Наказание за такое преступление - лишение покровительства сеньора. Остальные уголовные дела, случившиеся между горожанами, находились в компетенции шультгейса; $\S 14$ (=§ 47 ч. 1 Роделя) - норма о наказании зачинщика драки между горожанами; 16 (=\$§ 48-50 Роделя) - закон о наказаниях за ссору и вражду горожан вне стен Фрайбурга; $§ 17$ (=§ 53 Роделя) - установление наказания за вооруженное участие в мятеже; $\S 18$ (=§ 54 Роделя) норма о наказании за иск против согорожанина в нефрайбургском суде; $\S 23$ (=§ 60 Роделя) запрещает произвольные задержания фрайбуржцев без судебного решения. Исключение делается для фальшивомонетчиков и грабителей (вероятно, застигнутых на месте преступления); $\$ 30$ (=§ 38 Роделя) - запрет иногороднему свидетельствовать против фрайбуржца; $\S 32$ (=§ 37 ч. 3 Роделя) - наказание свидетелям тайного примирения тяжущихся горожан; $\S 36$ (=§ 32 Роделя) - закон о невозможности несовершеннолетнему распоряжаться имуществом родителей, разрешение родителям несовершеннолетнего не возвращать долги своего ребенка; $§ 62$ (=§ 43 Роделя) запрещал проводить судебный поединок негорожанина с горожанином, если последний не хотел его проведения; § 64 (=§ 40 Роделя) определял Кельн как город, где был арбитражный суд для Фрайбурга, и назначал комиссию для отправки в Кельн за решением.

11 параграфов отличаются от имеющихся в Роделе. $\S 9$ (изм. § 62 Роделя) дополняет норму о судьбе горожанина, потерявшего милость сеньора. Старый закон устанавливал, что такому горожанину разрешено в течении 6 недель проживать в городе и за его пределами и пользоваться собственностью. Движимость и недвижимость (городской дом указывался особо, потому что владение им было обязательным условием включения в городскую общину) запрещалось продавать и закладывать. Если за полтора месяца горожанин не вернет милость господина, то все его имущество (включая городской дом) доставалось сеньору. Особым пунктом указывалось, что если господин «ушел за гору» - ultra montana transieret (чит. за пределы городской округи), то для исполнения закона надлежало дожидаться его возвращения.

В новом законе говорится также, что потерявшему покровительство горожанину давался срок в полтора месяца для того, чтобы исправить ситуацию. Также разрешалось свободно пользоваться имуществом, однако снималось запрещение продавать и закладывать собственность в городе и за его стенами. Исключение делалось для городского дома, которым горожанин распоряжаться не мог, так как «он уже не горожанин». Изменялось наказание не сумевшему в 6 недель вернуть себе покровительство сеньора горожанину. Теперь господин мог изгнать его из города, но имущество при этом сохранялось за горожанином. Сеньор гарантировал безопасность жизни и сохранность имущества изгнанному, ему же разрешалось свободно проживать за городом. Такое дополнение стало важным для горожан и ограничило возможность городскому сеньору пополнять свою казну за счет фрайбуржцев, совершивших преступление. Преступник изгонялся, но его собственность (кроме городского дома) теперь переходила наследникам изгнанного. Кроме того, норма продемонстрировала правило, что за преступление, совершенное во Фрайбурге, полагалось исполнять наказание только внутри городских стен. Фрайбуржский преступник вне 


\section{ВЛАСТЬ И ОБЩЕСТВО}

города не считался таковым. Закон устанавливал также, что сеньор мог «простить» правонарушителя, тогда тот имел право свободно проживать в городе «пока господин захочет его охранять».

Далее новая норма изымала туманное сеньор ушел «за гору». Если господин находился «за пределами земли» - ussirthalp landes - то после его возвращения начинался срок в 6 недель, в течение которого горожанин должен был вернуть милость сеньора. Старый закон назначал срок в 6 недель сразу по решению суда, и если сеньор отсутствовал во Фрайбурге, то горожанину вернуть его покровительство было весьма проблематично.

По истечении полутора месяцев, если сеньор заявит, что горожанин его покровительства не вернул, а горожанин станет утверждать обратное, то фрайбуржец может предоставить двух свидетелей и доказать свою правоту. Таким образом, горожане пытались обезопасить себя от сеньориального судебного произвола и от необходимости дважды платить за одно и то же правонарушение.

Наконец, в течение 6 недель от вынесения приговора преступник мог свободно покинуть Фрайбург и пределы сеньориальных владений (указывались географические пределы его владений). Во время такого исхода сеньор обязан был защищать жизнь и собственность бывшего фрайбуржца.

$\S 10$ (изм. § 37 ч. 1-2 Роделя) указывает, что ни согорожане, ни шультгейс не имеют права заставлять поссорившихся фрайбуржцев подавать друг на друга жалобу (в Роделе нет конкретизации, к кому относился этот запрет, но в старом законе есть замечание, что сеньор и городской судья - iudex ciuitatis - не имеют право вести расследование по такому делу). В кратком проекте указывалось далее, что если иск все-таки попадал в суд, а тяжущиеся примирятся, и в этот момент кто-либо из них будет ранен другим, то сеньору или шультгейсу необходимо дело довести до конца. В Роделе же судьями, имевшими полномочия вести такое дело, по-прежнему указывались господин города и городской судья, а о ранении не упоминалось.

$\S 11$ (изм. § 44 Роделя) устанавливал наказание за побои, нанесенные согорожанину; за его смерть, вызванную такими побоя- ми (устанавливалось особое наказание за подобные преступления, совершенные ночью или в пьяном виде). Однако наказание следовало только если факт преступления подтверждали свидетели (в Роделе указывалось, что должно быть два достойных свидетеля duobus idoneis testibus). Наконец, если ответчик не был согласен с обвинением, он имел право вступить в поединок с жалобщиком или с одним из свидетелей (в Роделе только с одним из свидетелей).

$\S 12$ (изм. § 45 Роделя) постановляет разрушить дом бежавшего из Фрайбурга убийцы. Наследники могли восстановить стены дома только через год, уплатив шультгейсу 60 шиллингов (в Роделе - солидов). Преступника, вернувшегося назад в город, ждало положенное наказание. В кратком проекте устанавливалось дополнение, что наследники могли отказаться от восстановления дома, но также обязаны были уплатить шультгейсу судебную выплату - 60 шиллингов.

$\S 15$ (изм. § 47 ч. 2 Роделя) определяет наказание за избиение иногороднего фрайбуржцем. Новый закон устанавливает дополнение: за такое же преступление, но совершенное иногородним в отношении горожанина. В первом случае полагался штраф в размере 60 шиллингов (в Роделе - солидов), во втором - острижение волос преступнику на «два пальца» (zweier vinger). В новом законе как правонарушение сохранилось только избиение, но исчезло прописанное в Роделе: «лишить волос» (depilauerit).

$\S 19$ (изм. § 55 Роделя) гарантирует наказание иногороднему, преследующему фрайбуржца вне стен города. Горожанин, вернувшись во Фрайбург, должен был рассказать о возникшей ситуации шультгейсу, а затем, если иногородний приезжал во Фрайбург, то горожанин мог поступить со своим обидчиком как угодно. В новом законе, помимо «преследования» (iagen) указано «ранение» (wunden) как преступление, за совершение которого полагалось такое же наказание.

$\S 33$ (изм. § 39 Роделя) уточняет закон о свидетельских показаниях. В Роделе было указано, что в любом деле должны присутствовать два свидетеля, видевших и слышавших обстоятельства произошедшего. В кратком проекте уточнялось, что такие свидете- 
ли необходимы при расследовании дел об ограблении, когда сами они не просто «видели и слышали», но и могут опознать преступника.

$\S 35$ (изм. § 33 Роделя) устанавливает минимальный возраст правоспособности фрайбуржца: в кратком проекте - 12 лет, в Роделе - 14.

$\S 59$ (изм. § 72 Роделя) определял штраф в 3 шиллинга за нападение на проникшего в дом горожанина посетителя, которому вход в этот дом был запрещен. В Роделе штраф не полагался.

$\S 61$ (изм. § 42 Роделя) устанавливал, что со злоумышленником, который проник в жилище горожанина, можно было поступать как угодно. В Роделе конкретизировалось, что злоумышленник напал на горожанина в его доме или пленил его.

$\S 63$ (изм. § 74 Роделя) определял основания для проведения судебного поединка. В кратком проекте это «удар до крови», в Роделе кровопролитие, кража и убийство.

3 параграфа являются новыми для фрайбургского законодательства. § 31 содержит две нормы. Первая предусматривает, что горожанину и сеньору запрещается свидетельствовать друг против друга, за исключением дел о невыплате чинша и о тайном примирении ранее тяжущихся сторон. Закон явно ограничивал возможности господина города оказывать давление на местное судопроизводство. Вторая норма устанавливала возможность горожанину вернуть свое имущество, которое в свое время сеньор у него одолжил, но «забыл» (vergessin) вернуть. Вновь закон ограничивает возможность сеньора иметь право свободных реквизиций у горожан, защищает имущество горожан от непомерной жадности городского господина.

$\S 37$ продолжает норму 36-го параграфа (см. выше) о защите семейного имущества. Такие же ограничения в распоряжении собственностью налагались на жену фрайбуржца. Исключение делалось для семейных пар, которые были торговцами.

$\S 50$ продолжает закон об ограничениях возможностей сеньора присваивать имущество горожан (см. выше, § 31 ч. 2). Устанавливалось, что если господин возьмет что-либо у горожанина, то 24-ре должны были уговаривать сеньора вернуть горожанину его добро.
Если увещевания не помогут, то пострадавший и 24-ре объявляли о произошедшем во всеуслышание и тогда горожане получали возможность «не исполнять права перед господином»-dem herrin enhein reht tuie (чит.: не подчиняться сеньору), пока тот не возвратит захваченную собственность.

Уголовное и процессуальное право во Фрайбурге во второй половине XIII в. претерпевало изменения. Эти изменения были в пользу горожан и ограничивали возможности чужаков (негорожан, сеньора и сеньориальной администрации) влиять на городское судопроизводство, иметь преференции в суде по сравнению с членами городской общины.

Третий блок - гражданское право. 8 параграфов являются прямым переводом норм Роделя: $\S 21$ (=§ 57 Роделя) гарантирует необратимость законной сделки с имуществом; § 22 (=§§ 58-59 Роделя) постановляет законность продажи имущества и устанавливает ответственность за продажу краденного; § 34 (=§ 24 Роделя) определяет судьбу выморочного наследства; определяет права наследования родительского имущества детьми покойных; § 38 (=§§ 25-26 Роделя) устанавливает партнерские отношения мужа и жены в семейном предприятии (вероятно, в торговле) и в праве наследования; $§ 40$ (=§ 29 Роделя) устанавливает право наследования в семье, когда умер один из супругов и один из детей; $\$ 41$ (=§ 31 Роделя) устанавливает право наследования детьми материнского имущества, если отец ранее женился несколько раз; $\S 43$ (=§ 35 Роделя) определяет штраф за оскорбление фрайбуржки; $\$ 44$ (=§ 71 Роделя) запрещает принуждение вдовы к повторному браку или отказу от такового.

4 параграфа отличаются от имеющихся в Роделе. $\S 20$ (изм. § 56 Роделя) устанавливает правило взыскания долга с иногороднего. В Роделе было указано, что должника-негорожанина необходимо привести в суд, а судья должен заключить такого должника под стражу на 6 недель. Содержать его в заключении надлежало за счет кредитора, если у самого иногороднего не было собственных средств. По прошествии срока должник передавался кредитору, который мог отныне самостоятельно взыскать долг (вероятно за счет имущества задолжавшего). Кредитору 
же полагалось заплатить судебную пошлину в 3 солида и дать гарантию, что должнику не будет причинен вред.

Краткий проект делает дополнение, что, после того как должника передадут кредитору, первый должен постоянно находиться в городе так, «чтобы мог он солнце видеть», его надлежало хорошо кормить и регулярно предоставлять суду и 24-м для того, чтобы власти убедились в надлежащем обращении с задержанным. В данном случае закон дает дополнительную защиту иногородним, вероятнее всего купцам, для того, чтобы не нарушить торговые связи Фрайбурга с другими регионами, чтобы не «отпугнуть» иногородних купцов от городского рынка.

$\S 39$ (изм. §§ 27-28 Роделя) устанавливает право мужчине свободно распоряжаться семейной собственностью. После смерти одного из супругов и при наличии детей (в Роделе о детях не говорится) в семье вдовец или вдова теряют право свободного отчуждения имущества. Исключение делается для случаев, когда такая семья крайне обнищает и станет голодать. Тогда необходимо принести клятву, а члены семьи получают возможность свободного распоряжения имуществом. В кратком проекте вводится еще одно условие: факт бедственного положения семьи должны подтвердить 24-ре. Таким образом, устанавливались дополнительные меры защиты семейной собственности.

$\S 42$ (изм. § 34 Роделя) дополняет старый закон об опеке. Норма устанавливает наказание за вред, причиненный опекаемым детям, совершенный из корыстных побуждений. В кратком проекте дополнительно устанавливается, что дочь горожанина, находящаяся под опекой, не может «навредить себе» (речь, вероятнее всего, идет о возможности распоряжения имуществом), даже если опекун заботится о своей опекаемой недобросовестно.

$\S 52$ (изм. § 66 Роделя) меняет формулировку в законе о залоге собственности. В Роделе было установлено, что получивший в залог наследственное имущество пользуется им, пока не будет принесена клятва (речь идет о судебном заседании, в ходе которого наследственная собственность переходила другому владельцу). Если кто-либо отказывался принести клятву, то собственность «возвращается под власть господского права» (in domini iure redit potestatem). В этом случае с определенной степенью уверенности можно говорить о расторжении залоговой сделки участников.

Краткий проект настолько изменил сложные для восприятия формулировки Роделя, что, по сути, создал новый закон: в документе указывается, что отдавший в залог наследственную собственность обязан платить за нее чинш сеньору города. Если этого не происходит, то собственность не возвращается бывшему владельцу.

5 параграфов являются новыми для фрайбургского законодательства. § 45 устанавливает право овдовевшего родителя проживать у детей. Это право гарантируется городской общиной.

$\S 46$ постановляет, что если горожанин использует имущество своих детей, но потом «изменится его жизнь без его ведома»-wandilot daz denne sin lebin ane sine wissende (в данном случае речь идет об утрате такого имущества либо его части детьми), то такой случай (в этой части закона он уже определен конкретнее как «дар» - gift) не будет иметь законной силы, так как произошел не по воле отца.

$\S 47$ устанавливает возможность отцу передавать при своей жизни любому из детей часть своего имущества. Однако далее оговаривается ситуация, в которой получивший такую собственность ребенок умирает. В таком случае отец должен разделить такое имущество между оставшимися детьми: большую часть отдать одному из детей по своему выбору, а меньшую часть разделить между остальными.

$\S 48$ разрешает ситуацию, которая возникала после смерти горожанина-должника не имевшего наследников, но у которого при жизни был поручитель. Имущество покойного доставалось поручителю, а последний был должен выплатить долг из полученного наследства.

$\S 49$ нормирует случай, когда горожанин имел собственность в деревне, которая была под залогом, но эта собственность сгорела. В таком случае он имел возможность сохранить за собой землю, на которой ранее стояло строение.

Законы гражданского права защищают семью и семейное имущество горожан, развивают наследственное право и, кроме того, совершенствуют нормы о взаимоотношениях с иногородними в рамках гражданско-правовых законов. 
Четвертый блок - муниципальное управление. 2 параграфа являются прямым переводом норм Роделя: $\S 55$ (=§ 76 Роделя) разрешал членам Совета 24-х не платить чинш (в этом параграфе, как и в Роделе, суммой чинша называют 12 денариев, а в § $2-1$ шиллинг пфеннигов) сеньору за свой домовой участок, а также не являться в суд по какомулибо иску против себя, если советника за день не предупредили о заседании или же если он нарушил городское право; § 56 (=\$§ 77-78 Роделя) говорит о рабочих местах советников для исполнения своих обязанностей.

2 параграфа отличаются от имеющихся в Роделе. $§ 57$ (изм. § 20 Роделя) устанавливает, что все меры веса (в Роделе - меры измерения для вина, зерна и веса для золота и серебра) находятся под контролем 24-х. Точные меры должны выдаваться горожанам бесплатно (в Роделе после установления эталонных мер советники передавали их горожанину, которого считали достойным). Пользование неэталонными мерами в городской торговле приравнивалось к краже.

$\S 58$ (изм. § 79 Роделя) определяет полномочия Совета 24-х. В Роделе указывается, что в круге полномочий консулов лежат дела о регулировании правил торговли на рынке продовольственными товарами. В $§ 58$ краткого проекта это положение отсутствует. Полномочия 24-х к 1275 г. значительно расширились, и это видно из содержания предыдущих параграфов (см., напр. $§ 20, \S 50$ и др.), и не ограничивались более рыночными делами. Также Родель постановляет, что нарушивший клятву советник лишался имущества в городе. Краткий проект только лишь отменял незаконные постановления советников, но никак не наказывал нерадивых членов Совета. Кроме того, § 58 утверждал, что постановления советников являются законом, неисполнение которого лишает нарушителя права города.

Один параграф является новым для фрайбургского законодательства. § 65 определял, что после смерти члена Совета 24-х, «другие и не обычные» (andirn / unde nût mcenlich) горожане (вероятнее всего, остальные члены Совета) выбирают нового советника и приводят его к присяге.

Законы блока «муниципальное управление» показывают, что полномочия Совета в городе значительно расширились. Сам Совет 24-х превращается в полноценный законодательный и исполнительный орган муниципальной власти.

Пятый блок - торговое право. Все 11 параграфов являются прямым переводом норм Роделя: $§ 71$ (=§ 11 Роделя) обязывает сборщика податей [в кратком проекте - der zolner, в Роделе - телонеарий (thelonearius)] содержать в порядке мосты и возмещать убытки за падеж скота на неисправных мостах; $\$ 72$ (=§ 12 Роделя) устанавливает суммы торговых пошлин за проданные товары (по списку); 73 (=§ 12, § 6 Роделя) освобождает горожан от уплаты пошлины, устанавливает обязанность негорожан платить полную пошлину; $§ 74$ (=§ 30 Роделя) разрешает чужаку, купившему товар у горожанина, платить половину пошлины; $§ 75$ (=§ 15 ч. 1 Роделя) устанавливает обязанность хранителя общественных мер веса выдавать их горожанину в прокат под залог 3 шиллингов (в Роделе 3 coлидов); $§ 76$ (=§ 15 ч. 2-5 Роделя) устанавливает ответственность за отказ выдать общественные меры веса и за выдачу неверных мер; § 77 (= § 16 Роделя) определяет наказание за взимание платы за выдачу общественных мер веса; $\S 78$ (= § 17 Роделя) обязывает негорожанина платить обол за каждый взвешенный на общественных весах центнер; $\S 79$ (= § 14 Роделя) освобождает монахов, священников и служилых людей [dienestman, в Роделе - министериалов (ministeriales)] сеньора от выплат торговых пошлин; $\S 80$ (= § 18 Роделя) позволяет горожанам иметь эквивалент эталонных мер, с помощью которых можно торговать только с согорожанами; § 81 (= § 19 Роделя) устанавливает обязанность торговать с негорожанами только при использовании общественных мер веса.

Торговое право не претерпело изменений по сравнению с Роделем и по-прежнему регулировало правила взимания торговых пошлин.

Шестой блок - разные законы. 2 параграфа являются прямым переводом норм Роделя: $§ 60$ (=§ 73 Роделя) устанавливает возможность принудить к браку молодых, вступивших в интимную связь; § 66 (=§ 21 Роделя) разрешает горожанину пользоваться любой недвижимостью, не платя фогту (верховному судье сеньориальной администрации) подати.

1 параграф отличается от имеющегося в Роделе - § 67 (изм. § 22 Роделя). В старом 
законе указывалось, что за две недели до и за две недели после праздника св. Мартина (11 ноября) мясникам запрещалось покупать коров и свиней, если только животных не приготовили для убоя ради продажи мяса на вес. В кратком проекте особо устанавливалось, что мясо должно было доставаться и богатым, и бедным, а если мясник не исполнял этого закона, то должен был отвечать перед коллегией 24-х.

3 параграфа являются новыми для фрайбургского законодательства. § 68 постановлял, что купивший во Фрайбурге монету или владеющий ею должен был предоставить ее на контроль 24-м и горожанам. Этот закон был предназначен для контроля над чеканщиками монеты и недопуска в оборот фальшивых монет.

$\S 69$ устанавливал, что в случае неявки горожанина в суд сеньора назначался штраф в 60 шиллингов. Тот же параграф указывал, что членов Совета 24-х надо было вызывать в господский суд каждого по отдельности.

$\S 70$ определял минимальный штраф в пользу сеньора - 60 шиллингов.

Результаты. Краткий проект 1275 г. не стал официальной фрайбургской хартией. Однако это не умаляет его значения как ценного исторического источника по истории средневекового Фрайбурга. Документ, с одной стороны, отражал изменения, произошедшие в городском законодательстве с 1218 по 1275 гг., a с другой - показывал стороны политической борьбы, происходящей между городским (старшим) Советом 24-х, сеньором Фрайбурга и городской общиной.

На первый взгляд, краткий проект содержит большое количество норм, «не выгодных» сеньору [5, Bd. I, S. 293]. Это и ограничение господского произвола в отношении имущества горожан, и уменьшение влияния самого сеньора и его администрации в городском суде, при управлении городом и т. п. Но, несмотря на это, краткий проект без сомнения укреплял власть графов фон Фрайбургов в городе. Сеньор вновь должен был получить законодательную инициативу, вернуть себе возможность издавать законы во Фрайбурге, контролировать местные приходы.

Несомненные выгоды получал Совет 24-х. Краткий проект превращал надзорную рыночную коллегию муниципального управления в полноценный законодательный и исполнительный орган власти. Постановления Совета приравнивались к закону, советники принимали участие в судебных заседаниях, решали важные для города проблемы.

Городская община, напротив, теряла привилегии, полученные ранее. Горожане теперь не выбирали городского священника, шультгейса, а выборы членов Совета 24-х проходили уже без широкого участия городских жителей.

Вполне определенно можно сказать, что изменения в уголовном, процессуальном, гражданском праве, зафиксированные в кратком проекте 1275 г., отражали реально существовавшее законодательство Фрайбурга. Большинство норм, и об этом можно говорить с определенной долей вероятности, уже были введены в городе казуальными судебными решениями, постановлениями Советов и т. д.

\section{СПИСОК ЛИТЕРАТУРЫ}

1. Блохин, П. А. Две «одинаковые» фрайбургские хартии 1275 г.: cui bono? / П. А. Блохин // Средние века. - 2020. - Вып. 81 (2). - С. 92-110. - DOI: https://doi.org/10.7868/S013187802002004X.

2. Блохин, П. А. К вопросу о причинах создания фрайбургской учредительной привилегии / П. А. Блохин // Право в средневековом мире : сб. ст. / под ред. И. И. Варьяш, Г. А. Поповой. М. : ИВИ РАН, 2007. - С. 71-85.

3. Блохин, П. А. Эволюция фрайбургского городского права в XII - первой половине XIII вв. : автореф. дис. ... канд. ист. наук / Блохин Павел Александрович. - М. : ИВИ РАН, 2014. -20 с.

4. Городское право Фрайбурга // Средневековый город : прил. к ежегоднику «Средние века». М. : ИВИ РАН, 2006. - Вып. 1. - С. 15-42.

5. Blattmann, M. Die Freiburger Stadtrechte zur Zeit der Zähringer / M. Blattmann. - Freiburg ; Würzburg : Verlag Ploetz, 1995. - Bd. I-II. - 791 S.

6. Heinemeyer, W. Der Freiburger Stadtrodel. Eine palaographische Betrachtung / W. Heinemeyer // Zeitschrift der Savigny-Stiftung für Rechtsgeschichte. Germanistische Abteilung. - 1996. - 83. - S. 116-126.

7. Lahusen, I. Besprechung zu F. Beyerle (1910) / I. Lahusen // Göttingenische gelehrte Anzeigen. 1912. - 2. - S. 122-128.

8. Rietschel, S. Neue Studien über die älteren Stadtrechte von Freiburg im Breisgau mit einer vergleichenden Ausgabe der lateinischen Stadtrechtstexte des 13. Jahrhundert / S. Rietschel 
// Festgabe für Friedrich Thudichum. Tubingen, 1907. - S. 3-45.

9. Rörig, F. Nochmals Freiburger Stadtrodel, Stadtschreiber und Beischpruchsrecht / F. Rörig // Zeitschrift für die Geschichte des Oberrheins. 1912.-66, NF 27. - S. 16-32.

10. Urkundenbuch der Stadt Freiburg im Breisgau / hrsg. von H. Schreiber. - Freiburg, 1828. Bd. I, Abt. 1. $-224 \mathrm{~S}$.

\section{REFERENCES}

1. Blokhin P.A. Dve «odinakovye» frajburgskie hartii 1275 g.: cui bono? [Two «Identical» Freiburg Charters of 1275. Cui Bono?]. Srednie veka [Middle Ages], 2020, iss. 81 (2), pp. 92-110. DOI: https://doi.org/ 10.7868/S013187802002004X.

2. Blokhin P.A. K voprosu o prichinakh sozdaniia fraiburgskoi uchreditelnoi privilegii [To the Question of the Reasons for the Establishment of the Freiburg Constitutional Privilege]. Pravo $v$ srednevekovom mire: sb. st. [Law in the Medieval World. Collection of Articles]. Ed. by I.I. Variash, G.A. Popova. Moscow, Institute of World History of Russian Academy of Sciences, 2007, pp. 71-85.

3. Blokhin P.A. Evoliutsiia fraiburgskogo gorodskogo prava $v$ XII - pervoi polovine XIII vv.: avtoref. dis. ... kand. ist. nauk [Evolution of Freiburg
Town Law in the $12^{\text {th }}-$ First Half of $13^{\text {th }}$ Centuries: Cand. hist. sci. abs. diss.]. Moscow, Institute of World History of Russian Academy of Sciences, 2014. 20 p.

4. Gorodskoe pravo Fraiburga [Freiburg Town Law]. Srednevekovyi gorod: pril. $k$ ezhegodniku "Srednie veka» [Medieval Town. Annex to Journal "Middle Ages"]. Moscow, Institute of World History of Russian Academy of Sciences, 2006, iss. 1, pp. 15-42.

5. Blattmann M. Die Freiburger Stadtrechte zur Zeit der Zähringer. Freiburg; Würzburg, Verlag Ploetz, 1995, Bd. I-II. 791 S.

6. Heinemeyer W. Der Freiburger Stadtrodel. Eine palaographische Betrachtung. Zeitschrift der SavignyStiftung für Rechtsgeschichte. Germanistische Abteilung, 1996, 83, S. 116-126.

7. Lahusen I. Besprechung zu F. Beyerle (1910). Göttingenische gelehrte Anzeigen, 1912, 2, S. 122-128.

8. Rietschel S. Neue Studien über die älteren Stadtrechte von Freiburg im Breisgau mit einer vergleichenden Ausgabe der lateinischen Stadtrechtstexte des 13. Jahrhundert. Festgabe für Friedrich Thudichum. Tubingen, 1907, S. 3-45.

9. Rörig F. Nochmals Freiburger Stadtrodel, Stadtschreiber und Beischpruchsrecht. Zeitschrift für die Geschichte des Oberrheins, 1912, 66, NF 27, S. 16-32.

10. Urkundenbuch der Stadt Freiburg im Breisgau. Hg. von Schreiber H. Freiburg, 1828, Bd. I, Abt. 1.224 S.

\section{Information About the Author}

Pavel A. Blokhin, Candidate of Sciences (History), Associate Professor, Department of Foreign History \& Regional Studies, Astrakhan State University, Tatishcheva St, 20a, 414056 Astrakhan, Russian Federation, pavelblochin@yandex.ru, https://orcid.org/0000-0002-5104-755X

\section{Информация об авторе}

Павел Александрович Блохин, кандидат исторических наук, доцент кафедры зарубежной истории и регионоведения, Астраханский государственный университет, ул. Татищева, 20a, 414056 г. Астрахань, Российская Федерация, pavelblochin@yandex.ru, https://orcid.org/0000-0002-5104-755X 